\title{
GONDOLKODIK-E AZ EMBERI AGY?
}

\section{DOES THE HUMAN BRAIN THINK?}

\author{
Pléh Csaba \\ az MTA rendes tagja, Közép-európai Egyetem Kognitív Tudományi Tanszéke \\ vispleh@ceu.edu
}

\begin{abstract}
ÖSSZEFOGLALÁS
A gondolkodás mindig viszony a gondolat tartalma és tárgya között, így csak az egész emberhez kapcsolható. Az esszé ezen az általános tézisen túl bemutatja, hogyan ihleti a filozófia még ma is a kísérleti pszichológiát. A tudatelmélet, a prototipikus elvű kategóriaszerveződés és Quine gavagai paradoxonának feloldásán - megszorítási elvek a szótanulásban -, példáján mutatja be, hogy az empirikus pszichológiai kutatás állandó fordítás a filozófia nyelve és a természettudományos nyelv között.
\end{abstract}

\section{ABSTRACT}

Thinking is always a relation between the content of thought and object, so it can only be associated to the whole person. Beyond this general thesis, the essay shows how experimental psychology is still inspired by philosophy. The empirical psychological research means a constant translation between language of philosophy and natural science. This will be demonstrated through the case of the theory of consciousness, the prototype-based category organization and disentanglement of the Quine's gavagai paradox - the principles of constraints in lexical acquisition.

Kulcsszavak: test-lélek, tudatelmélet, intencionális hozzáállás, prototípus, kategorizáció, gavagai paradoxon, szótanulás, lexikai megszorítások

Keywords: body-mind, ToM, intentional stance, prototype, categorization, gavagai paradox, lexical acquisition, lexical constraints

A címmel kicsit csapdába kerültem. Nyíri Kristóf és Fábri György kérte, hogy ezzel a címmel tartsak előadást ezen az összejövetelen. Ök orientálták, hogy mi is legyen a cím. Nyilván arra gondoltak, hogy tartsak valami antiredukcionista előadást. Én a csapdát igyekszem kikerülni. Nem pontosan arról fogok beszélni, ami az előadás címe. Csupán röviden fogok említeni százötven éves vitákat arról, 
hogy az agy vagy az ember gondolkodik. Igazi mondanivalóm az lesz, hogy a természettudományos irányultságú pszichológusnak is érdemes filozófiai ihletést merítenie.

A modern anatómia és élettan fejlödésével bontakozott ki az a kérdéskör, mely százötven éve viták tárgya, hogy vajon a kiinduló test-lélek kérdés felvetései közben miféle fordítási gondokba ütközünk. Ezeknek a kérdéseknek az értelmezésében ugyanis többszörös fordítási problémákról van szó a különböző életszférák és a nekik megfeleltetni szándékozott diszciplínák között. A kísérleti pszichológia filozófiai, illetve a mủveltségből származó kérdéseket fordít le a laboratóriumi helyzetek nyelvére, s ezt értelmezi azután az idegtudós. Eközben nem az agy, hanem az ember gondolkodik, s a kutató számos fordítást végez a szemléletek között.

A fordítások fordítás volta e kifejezés legkézenfekvőbb értelmében is elveszik néha a tudósok számára. Sokszor azt sem veszik észre, hogy már az állati idegrendszer teljesítményeivel is többszörös fordításban foglalkoznak. Hadd mondjak egy egyszerü, még az idegrendszeri képalkotás forradalma előtti példát. Egy nemzedék óta vizsgálják különböző főemlősök tárgyfelismerését, egyszerü majmoktól a csimpánzokig. Azok a természettudósok, akik ezt a kérdést vizsgálják, egysejt-tevékenység rögzítésén alapuló elegáns elméleteket alakítanak ki arról, hogy a halántéklebenyben sajátosan tárgyspecifikus kategóriák vannak (bemutatására lásd Kovács, 2004). Saját maguk sokszor észre sem veszik, hogy miközben tárgyfelismerésröl beszélnek (object recognition areas in monkeys és hasonlók), valójában képeket vetítenek az állatoknak. A laboratóriumokba nem cipelnek be fákat, amikor kimutatják, hogy a rhesusmajom képes megtanulni a 'fák' és 'nem fák' megkülönböztetését. Vagyis a természettudós nem is veszi észre, hogy milyen csapdákat állít önmagának a képek és tárgyak mintegy váltogatásával.

\section{A LOKALIZÁCIÓ KORLÁTAI}

Az egyik nagyon fontos általános kérdés, amelyre emlékeznünk kell, s melyben a filozófusok sokat segítenek a kísérletezőknek, a ,gondolkodás helyével”, e kartéziánus dilemmával kapcsolatos. A mai funkcionális idegrendszeri képalkotási módszerek burjánzása közepette emlékezzünk arra, hogy nem elég tudni azt, hogy valami hol történik. Azt is tudni kell, hogy mi az, ami valahol történik, még ha hinnénk is abban, hogy a gondolkodás egyáltalán valahol történik. Ez nagyon sokszor elfelejtódik, miközben a képalkotás maga csak anyagcsere-folyamatok eredményeit mutatja, s nem azt, hogy egy adott „hely” az állati vagy emberi agyban például szófelismerést végez. Ezt máshonnan, abból tudjuk, ahogyan a kísérleti kutató lefordította a laboratóriumi ingerhelyzet nyelvére a felismerés kérdését, s például vegyes betühalmazokat (tkuay) állított szembe nyomtatott szavakkal (kutya). 
A lokalizáció kizárólagossá tételének két veszélye az eltekintés az egyéni eltérésektől, továbbá az a hit, hogy a magasabb megismerési folyamatoknak egyetlen lehetséges mintázatuk van, miként William R. Uttal (2001) kritikája rámutatott. Ehhez hozzátehetjük a neurális körök kérdését: a kérgi müködések térképei izgalmi és gátlási információt kell hogy szerezzenek más agyi területekről. Tartalmilag fontos korlát, hogy az összetett megismerő müködések (emlékezet, olvasás, nyelv s hasonlók) általában számos alfolyamatból állnak össze. A funkcionális idegrendszeri képalkotás itt valójában arra kényszeríti a pszichológust, hogy újrafogalmazza a funkcionális szerveződést. Abból, hogy hol történik valami, még nem tudjuk, mi is történik ott. Ahogy Kéri Szabolcs és Gulyás Balázs (2003) magyar idegtudósok és pszichiáterek másfél évtizeddel ezelőtt megfogalmazták már, az agyi tevékenység nem csupán anyagcsere-tevékenység, amit a képalkotó eljárások kimutatnak. Van egy viselkedési oldala, egy elektromos oldala s egy neurotranszmitter oldala is. ,Az idegrendszeri képalkotó vizsgálatok a viselkedés és a neuronális tevékenység között kívánnak kapcsolatot feltárni. Az ilyen idegrendszeri együttjárási megközelítések alapterminusai az észleléssel, mozgató müködéssel, emlékezettel, nyelvvel, érzelmekkel, sőt akár az öntudattal kapcsolatban is igen elégtelenül meghatározottak. Elöször is, milyen idegrendszeri tevékenységet keresünk? Figyelembe kell vennünk a neurotranszmitter müködések összetett dinamizmusát (szintézis, átvitel, kijutás, receptor müködés és visszavétel), az elektromos tevékenységet, a mögöttes anyagcsere-folyamatokat és véráramlási változásokat. [...] Viszonyukat nem eléggé értjük, bár számos vizsgálat épít arra a feltevésre, hogy ezek akár egymással helyettesíthetőek is lennének." (KériGulyás, 2003, 1103.)

Az új frenológia fenyegetésének elkerüléséhez a funkcionális idegrendszeri képalkotást világos elképzelésekkel kell összekapcsolni egy adott kognitív terület funkcionális szerveződéséről (Tiberghien et al., 2007). Stanislas Dehaene (2007) francia idegtudós és pszichológus világosan megfogalmazta, miről is van itt szó. Az agytérképezés csak az első lépés, ezt az érintett folyamatok részletes modellálásának kell követnie, szem előtt tartva, hogy többnyire kétirányú, egy a többhöz viszony van a pszichológiai müködések és a mentális müveletek között, ami sokszoros levetítéseket eredményez az egyszerü frenológiai térképek helyett. George Mandler egy korábbi nemzedék vezető kognitív pszichológusainak hozzáállását rögzítette. „Egyelöre még mindig csupán azt halljuk, hogy »ha megmondod, hol van a nyelv, attól még nem tudom, mi a nyelv, vagy mi a szerepe«, ami érvényes az emlékezetre, az érzelemre s így tovább. Az idegtudomány például nem tudja leírni a különböző viselkedéseket és élményeket létrehozó társas vagy kulturális feltételeket, s továbblépve, a pszichológia nem ismeri azokat a hasonló vagy azonos mechanizmusokat, melyek láthatóan eltérő viselkedésekért és élményekért felelősek." (Mandler, 2011, 242.) 
Magam sem hiszem, hogy a gondolati tartalom lokalizálható lenne. Inkább azzal értek egyet, hogy a gondolati tartalom mindig egy viszonyban létezik, alapkérdése a brentanói intencionalitás, tárgyi vonatkozás, gondolati tartalom és a gondolat tárgyának viszonya. Kutatása viszont kérdés az érintett diszciplínák között is. Amikor a laboratóriumi pszichológusok ezt vizsgálják, többnyire a gondolkodáskutatás klasszikus hagyományából, és ezen a hagyományon belül a filozófiából indulnak ki. Arra vonatkozó reflexióból, hogy milyen dolgok is vannak egyáltalán, melyekre gondolni lehet, s milyen módokon gondolhatunk rájuk (Brentano, 1911/1994).

A gondolati leképezések és az idegrendszeri „helyek” esetleges megfeleltetésének kérdése természetesen a filozófia és a természettudomány az agy szerepét kiemelő első törekvéseitől velünk van. Nagyon élénken került azonban előtérbe a modern idegkutatás első lépéseinek kritikájától Henri Bergsonnál. Bergson már a 19. század végén észrevette azt a problémát, hogy az agy nem értelmezhető úgy, mint emlékek vagy képzetek tárháza. Tőle származik az a gondolatmenet, hogy a test, az agy valójában nem közvetlenül reprezentációs tevékenységet végez, ez egy bonyolultabb dolog. ,Miközben az agyfiziológia egyre jobban lokalizálni tudta az érzéseket és a mozgásokat, a gondolatokat nem sikerült [...]. A hipotézist olyan nyelvezetben álcázták, amit az anatómiának és a fiziológiának kölcsönöztek, de ez nem egyéb, mint a lelki élet asszociacionista felfogása." Az agy biztosítja, hogy a jelen helyzet s az emlékezés kapcsolatba kerüljön a múlttal, „,eszközt nyújt arra, hogy a jelen valósággal kapcsolatban visszanyerjünk egy elveszett hatást: az agy azonban semmiképpen sem emlékek vagy képzetek tárháza. A test tehát sem az észlelésben, sem az emlékezetben, s különösen nem a szellem magasabb müveleteinél nem járul közvetlenül hozzá a reprezentációhoz" (Bergson, 1896, 137., 253-254.).

Nyilván sokféle értelmezése van ennek a bergsoni hagyománynak. Henri Bergson legfőbb érvét, hogy nincsenek kategóriaspecifikus kiesések (például valaki csak a bútorokat nem ismeri fel) a mai idegtudomány igencsak megkérdőjelezi. Nekünk itt most az a fontos, hogy amikor a kísérleti pszichológusok saját munkáikat értelmezik, fontos Bergsonnak a lokalizációval szembeni kételyeire emlékezniük. Fontos azt is tudnunk, hogy Bergson hozzáállásának vannak mai követői is. Paul Ricoeurtől származik a bergsoni hagyomány radikális értelmezése az utóbbi néhány évtizedben. Szerinte valójában a szakadék nem is a neurális értelmezés és a kísérleti pszichológia között, tehát nem is a fiziológiai redukcionizmus világában van, hanem már akkor, amikor a kísérleti pszichológus a fenomenális élményt megpróbálja lefordítani a saját laboratóriumi nyelvére. „Számomra a megkülönböztetés nem annyira a pszichológia és az idegtudomány közt érvényes. A szakadék talán már a pszichológia és a fenomenális élmény közt megvan. A tudat nem doboz, melyben tárgyak lennének. [...] A fenomenológia szakított a tartály-tartalom viszonnyal, mely a pszichikumból egy helyet csinált. Egyáltalán 
nem fogadhatom el azt a koncepciót, mely a szellemből tartályt csinál." (Ricoeur in Changeux-Ricoeur, 2001, 59.) Ricoeur fenomenológiába bezártságával mi, többségnek tűnő kisebbség, a kísérletezők néhány tízezres közössége radikálisan nem értünk egyet. Rövid példáim arról fognak szólni, hogy igen is jogos a fenomenális élményt vagy a kulturális hagyományt lefordítani a laboratórium szikár nyelvezetére. Három 20. századi tudománytörténeti példán akarom illusztrálni, hogyan megy végbe a valóságban a filozófia lefordítása a kísérletezés nyelvére. Eközben kikerülöm a címbeli csapdát, s nem fogok a redukcionizmus kérdéséröl beszélni és állást foglalni. A tudatelmélet, a szemantikai prototípusok és a szókincs elsajátításának rejtett elvei példáján mutatom meg, hogy minket, földhözragadt kísérleti pszichológusokat hogyan inspirálnak filozófiai olvasmányaink bizonyos kísérleti iparágak elindításában. Az iparág itt nem pejoráló kifejezés akar lenni, maguk a filozófusok is így hivatkoznak saját sikereikre.

\section{TUDATELMÉLET ÉS GONDOLATOLVASÁS}

Első példám a tudatelmélet (Theory of Mind) problémája. Daniel Dennett az a ritka filozófus a mai világban, aki nemcsak értelmezi a természettudományok eredményeit, naprakészen olvassa és ismeri a természettudományt, akárcsak egy évszázada Bergson, de más értelemben is kulcsszereplö. Miközben az analitikus filozófiából indul ki, úgy gondolja, hogy nincs igazi szakadék az analitikus filozófia és az úgynevezett kontinentális filozófiai hagyomány között. Az analitikus filozófia fogalmi elemző keretébe emel be olyan fogalmakat, például az intencionalitást, amelyek hagyományosan a kontinentális filozófia szívéhez közelebb álló fogalmak (Dennett, 1998). Dennett saját maga is észrevette - s ezt a sikert nevezi egy iparág elindításának -, hogy az egyik alkalmi megjegyzése, amit 1978-ban füzött a legelső modern, az úgynevezett tudatelmélet vagy gondolattulajdonítás problémáját elemző kísérleti cikkhez, sok száz hivatkozással elindította a gondolattulajdonítás kísérleti iparágát. David Premack és Guy Woodruff (1978) cikke egy otthon nevelt csimpánzzal folytatott alkalmi kísérleteken alapszik. Azt elemezték, hogy képes-e az emberi otthonban nevelt csimpánz gondolatokat tulajdonítani a valamilyen dolgokat csináló embernek. A csimpánzok videókat néztek arról, hogy az emberi személy elvesztette a kulcsát, és szeretné megtalálni a szekrény alatt. Az ember nevelte csimpánz mindezt úgy értelmezte, ahogy mi, emberek is, vagyis hogy az emberi személy valamilyen célirányos tevékenységet folytat. „Feltételezve, hogy más egyének akarnak, gondolnak, hisznek dolgokat s így tovább, olyan állapotokat következtetünk ki, melyek közvetlenül nem megfigyelhetőek, s ezeket az állapotokat anticipációs módon használjuk, mások és saját viselkedésünk bejóslására." (Premack-Woodruff, 1978, 525.) Dennett (1978) kis hozzászólása, miközben a kérdést elhelyezte az inten- 
cionalitás filozófiai hagyományában, mivel felvetette az alternatív vélekedések, a téves vélekedések vizsgálatának lehetőségét, valójában elindította a hamis vélekedés kísérleti hagyományának iparágát. Az állatokra nézve, mint Josep Call és Michael Tomasello (2008) harminc év kutatásait összegezte, a csimpánzok képesek mások szándékainak és céljainak értelmezésére, de nem tudnak magasabb szintủ tudatelméletet kiépíteni, téves vélekedéseket tulajdonítani másoknak, szembeállítva sajátjukkal.

Ennek az „iparágnak” sajátos megjelenési formája az intencionalitásértelmezés preverbális gyermekeknél. Gergely György és munkatársai szerint (1995) 12 hónapos babák már racionálisan értelmeznek animációs útvonalakat. Felteszik, hogy szándékosan mozgó tárgyakat látnak, melyek a célt a legrövidebb úton próbálják elérni. Vagyis az ,intencionális tulajdonítás” már jelen van preverbálisan, 12 hónapos gyermekeknél is. A nézési idők és a meglepetéseik szerint a 12 hónapos gyermekek is úgy értelmeznek ábrákat, mint ahol a mozgó tárgy akadályt ugrik át. Ha elkerül az akadály az útból, s a tárgy továbbra is ugrik - vagyis nem célracionális -, akkor a baba meglepődik. Ebben a gondolatmenetben, amikor ők ezt vélelmezik, két ihletőjük volt. Az egyik Fritz Heider és Marianne Simmel (1944) szociálpszichológiai kísérletei az 1940-es évekből. Ezek voltak a vizuális figurák alapjai, akik felnőttnél vizsgáltak hasonló szándéktulajdonítást. A másik Dennett intencionalitás elmélete. „Dennett (1998) a mellett érvelt, hogy az intencionális hozzáállás magját a racionalitás alapelve adja. [...] A csecsemők adatai további tapasztalati alátámasztását adják a racionalitás alapvető szerepének a viselkedés intencionális értelmezésében.” (Gergely et al., 1995, 190.) Az érdekes most számunkra az, hogy itt a filozófiai kérdésfeltevés válik egy sikeres kísérleti irány elindítójává. Az intencionális hozzáállás fenomenológiai filozófiai ihletésü fogalmát lefordítják a kísérletezés nyelvére.

A mások elméje és a „gondolatolvasás” mint átfogó filozófiai és szakmai kérdések azóta is középpontban állnak mind a szaktudományokban (Kiss, 2005), mind a filozófiában (Márton et al., 2017).

\section{A CSALÁDI HASONLÓSÁGTÓL A PROTOTÍPUSOKIG}

A másik példám a prototípus-elmélet, Eleanor Rosch hagyománya. Rosch abból indul ki, hogy a filozófiában van egy szigorú, hierarchikus arisztotelészi és egy laza, wittgensteini hagyománya a fogalmak elemzésének. „Ezeket a hasonlóságokat nem tudom jobb szóval jellemezni, mint hogy »családi hasonlóság«-ok; mert így fedik át és keresztezik egymást azok a különböző hasonlóságok, amelyek egy család tagjai között állnak fenn: termet, arcvonások, a szem színe, a járás, a temperamentum stb. stb. És azt állítom, a »játékok« egy családot alkotnak." (Wittgenstein, 1992, 58.) 
Rosch és Carolyn B. Mervis (1975) ezt a fogalmat fordítja le a kísérletezés nyelvére. Alapgondolatuk szerint a kategóriatagok prototípusmértéke a többi kategóriataggal való családi hasonlóságuk függvénye (Rosch, 1975). Mit csinált Rosch technikailag? A családi hasonlóság filozófiai fogalmát aprópénzre váltotta. Ludwig Wittgensteinből kiindulva azt kezdte el nézni, hogy valami hasonló szerveződése van-e a spontánul megjelenő fogalmainknak. A jármüvek, az emlősállatok, a fük-fák-bokrok világának. Az eredmények szerint vannak legjobb esetek és vannak kategóriaszélek. A delfin például „rosszabb” emlős, mint a tehén, s így tovább.

Az így bevezetett prototípus-fogalom óriási karriert futott be azóta, magára a klasszikus cikkre mintegy 120000 szakmai hivatkozás történt. Nemcsak a kísérleti pszichológiában, hanem a humán tudományokban is. Számos részkérdés merül fel. Mi alakítja a prototípusokat, hogyan szerveződnek hierarchiákba a kategóriák, mi az alapszintek (például virág vagy kutya) szerepe, milyen az életkori alakulása a prototípus köré szerveződő és az éles határú fogalmi osztályozásnak. Egy nemzedékkel korábban adtam erről egy összefoglalót (Pléh, 1997), de a téma máig élénken él.

\section{A SZÓKINCS-ELSAJÁTÍTÁS MEGSZORÍTÁSAI}

A harmadik példámban a filozófia elindította empirika visszavisz a realitáshoz, felold egy filozófiailag feloldhatatlannak tünő rejtélyt. A szókincs-elsajátítás rejtett elveiről van szó. Eddig azt láttuk, hogy átveszünk egy filozófiai fogalmat, és értelmezzük. Itt viszont egy filozófiai paradoxonból indul ki az empirikus kutató, $\mathrm{s}$ az empíria egy kicsit visszavisz a józan ész realitásához. Willard Van Orman Quine (1960/2002) híres paradoxona a gavagai paradoxon. Képzeljünk el egy antropológiai nyelvészt, aki az adatközlöjével üldögél, s ,felkiált, hogy gavagai!, miközben egy nyúl fut át elöttük, az idegen elvileg nem tudhatja, hogy a gavagai a nyúlra, a futására, a nyúl valamelyik testrészére vagy a színére, esetleg más tulajdonságára utal; végtelen számú különböző dolgot jelenthet" (Lukács, 2014, 548.).

A kísérleti pszichológusok s különösen a fejlődési kísérletezők elkezdték ezt a paradoxont lefordítani a kísérletezés nyelvére. Olyan kísérleteket készítenek, ahol egy új, ismeretlen, kissé fura tárgyat mutatnak fel, s egy új tárgy vagy tulajdonság nevét adják meg, s eközben kíváncsiak arra, mire értelmezi az új komplexumot a gyermek. Néhány egyszerủ elvet követünk itt:

- A referencia elve.

- A kiterjeszthetőség elve.

- A tárgyhatókör elve.

- Taxonómiai megszorítás.

- A kölcsönös kizárás elve. 
A referencia elve vagy fönéviség elve szerint, ha új dolgokat hallunk, ha semmi nem mond ennek ellent, azt gondoljuk, hogy az egy új megjelenő tárgyra, egy új vizualitásra vonatkozik mint fónév. A kiterjeszthetőség elve szerint a kifejezés a tárgy osztályának a neve, a székekre például általában vonatkozik. Vannak ebben taxonómiai megszoritások. Nem azt gondoljuk, ha egy új állatnevet hallunk, hogy az állatságról szól, de nem is, hogy az adott sün tulajdonneve. Hanem azt véljük, hogy az állatfajnak a neve. Sok ezer gyerekkel végzett kísérleti vizsgálat igazolta ezeket az elveket.

A társas tanulási-tanítási helyzet hatékonysága mellett ezek az elvek teszik érthetővé az embergyermek igen gyors szótanulását, azt, hogy három-négy társítás után tud már egy új szót. A kísérletezés tehát egy naiv ontológiai feltevésrendszerrel oldja fel a gavagai paradoxont. Itt a filozófia valójában válaszra provokálta a pszichológusokat. Lehet, hogy nem tudjuk az episztemológiai kérdést véglegesen megoldani, kiiktatni a gavagai paradoxont. De minket nem is az érdekel, hanem az, hogy a gyerek hogy oldja fel. Mert a gyerek azért csak-csak megtanulja a szavakat.

Röviden visszatérek az eredeti kérdésfeltevéshez. Hogyan is gondolkodunk mi, mai kísérleti pszichológusok a három szerveződési és tudományszervezési szint viszonyáról? Többnyire úgy gondoljuk, hogy a filozófiai hagyományból és a kultúrából, a kategóriaelemzésből kiindulva próbálunk meg viselkedéses kísérletekkel, sokszor egyenesen az élményböl kiindulva kimutatni valami új jelenséget, s ahhoz paramétereket kapcsolni, fejlődését tisztázni s így tovább. Azután az már a neurobiológus feladata, hogy megkeresse, ennek a szerveződésnek mi is a sajátos megfelelője az idegrendszerben. Maga az a lépés, ahogy egy hagyományos kategóriakérdést lefordítunk a kísérletezés nyelvére, soha nem hagyható ki. A viselkedéses kísérletezés felvet valóban új jelenségeket. Segít előrelépni a neurológiai realitás keresése felé. Eközben mindig a nehezen megmagyarázató hajt elöre, $\mathrm{s}$ nem csupán a redukció igénye.

\section{IRODALOM}

Bergson, H. (1896): Matiére et mémoire. Párizs: Alcan

Brentano, F. (1911/1994): Az erkölcsi ismeret eredete. Budapest: Kossuth Kiadó

Call, J. - Tomasello, M. (2008): Does the Chimpanzee Have a Theory of Mind? 30 Years Later.

Trends in Cognitive Science, 12, 187-192. DOI: 10.1016/j.tics.2008.02.010, https://www.researchgate.net/publication/5428900_Does_the_Chimpanzee_Have_a_Theory_of_Mind_30_ Years Later

Changeux, J.-P. - Ricoeur, P. (2001): A természet és a szabályok. Budapest: Osiris Kiadó 
Dehaene, S. (2007): A Few Steps Toward a Science of Mental Life. Mind, Brain, and Education, 1, 28-47. DOI: 10.1111/j.1751-228X.2007.00003.x, https://www.researchgate.net/publication/227658800_A_Few_Steps_Toward_a_Science_of_Mental_Life

Dennett, D. C. (1978): Beliefs about Beliefs. Behavioral and Brain Sciences, 1, 568-570. DOI: 10.1017/S0140525X00076664, https://dl.tufts.edu/catalog/tufts:ddennett-1978.00001

Dennett, D. (1998): Az intencionalitás filozófiája. Budapest: Osiris Kiadó

Gergely Gy. - Nádasdy Z. - Csibra G. et al. (1995): Taking the Intentional Stance at 12 Months of Age. Cognition, 56, 165-193. DOI: 10.1016/0010-0277(95)00661-H

Heider, F. - Simmel, M. (1944): An Experimental Study of Apparent Behavior. American Journal of Psychology, 57, 243-259. DOI: 10.2307/1416950

Kéri Sz. - Gulyás B. (2003): Four Facets of a Single Brain: Behaviour, Cerebral Blood Flow/Metabolism, Neuronal Activity And Neurotransmitter Dynamics. Neuroreport, 14, 1097-1106. https://www.ncbi.nlm.nih.gov/pubmed/12821790

Kiss Sz. (2005): Elmeolvasás. Budapest: Új Mandátum Könyvkiadó

Kovács Gy. (2004): A perceptuális kategorizáció alapjai. In: Pléh Cs. - Gulyás B. - Kovács Gy. (szerk.): Kognitív idegtudomány. Budapest: Osiris Kiadó, 202-216.

Lukács Á. (2014): Szótanulás. In: Pléh Cs. - Lukács Á. (szerk.): Pszicholingvisztika. Budapest: Akadémiai Kiadó, 539-568.

Mandler, G. (2011): Crises and Problems Seen from Experimental Psychology. Journal of Theoretical and Philosophical Psychology, 31, 240-246. DOI: 10.1037/a0023968

Márton M. - Molnár G. - Tözsér J. (szerk.) (2017): Más elmék. Budapest: L'Harmattan Kiadó

Pléh Cs. (1997): Hozzájárulhatnak-e az empirikus pszichológiai kutatások a nyelv-gondolkodás viszony filozófiai problémájának megoldásához. Magyar Filozófiai Szemle, 41, 439-538.

Premack, D. - Woodruff, G. (1978): Does the Chimpanzee Have a Theory of Mind? Behavioral and Brain Sciences, 1, 515-526. DOI: 10.1017/S0140525X00076512, https://www.researchgate. net/publication/232003352_Does_a_chimpanzee_have_a_theory_of_mind

Quine, W. O. (1960/2002): A tapasztalattól a tudományig. Válogatott tanulmányok. Budapest: Osiris Kiadó

Rosch, E. (1975): Universals and Cultural Specifics in Human Categorization. In: Brislin, R. Bochner, S. - Lonner, W. (eds.): Cross-cultural Perspectives on Learning. New York: Sage, 177-206.

Rosch, E. - Mervis, B. (1975): Family Ressemblances: Studies in the Internal Structure of Categories. Cognitive Psychology, 7, 573-605.

Tiberghien, G. - Guillaume, F. - Baudouin, J.-Y. (2007): La neuro-imagerie cognitive nouvel indicateur, nouvelle science ou nouvelle phrénologie? In: Vauclair, J. - Nicolas, S. (éd.): Localisation cérébrale des fonctions mentales : de la cranioscopie de Gall à l'IRMf. Marseille: Solal, 57-79.

Uttal, W. R. (2001): The New Phrenology: The Limits of Localizing Cognitive Processes in the Brain. Cambridge, MA: MIT Press

Wittgenstein, L. (1992): Filozófiai vizsgálódások. (ford. Neumer K.) Budapest: Atlantisz Kiadó 